\title{
On Cuban Stages: A Report from the Field
}

\section{Yael Prizant}

\section{Day 1 - May 27, 2009}

I've been doing research on Cuban and Cuban-American theatre for nearly 10 years, and I'm headed to Miami before my latest trip to Havana. It's been more than three years since I was in Cuba and I am eager to see what's on stage. For a non-Cuban American, the complicated processes for traveling to the island usually take weeks, if not months, to complete. On three of my previous theatre research trips, the paperwork to deal with U.S. travel restrictions, the specific license for academic research, and the unreliable, expensive charter flights were daunting enough to make me question whether or not my excursions were wise. However, this time, the Miami airport has hired extra staff to manage the flights to Cuba! The check-in lines are organized and marked, a major improvement over the chaos of past trips. On board the plane, the crew seems unprepared. The flight attendants don't speak Spanish and I'm asked to translate instructions for the passengers in the exit row. We land in Havana 80 minutes later.

At the terminal of José Martí airport, there are Cuban medical personnel wearing protective masks. They hand disembarking passengers cards explaining that there have been no reported cases of swine flu in Cuba and that the Cuban health department plans to keep it that way. The route from the airport to Vedado looks freshly repaired and much improved, with smooth asphalt and newly painted buildings. My taxi driver reveals that although it is four in the afternoon, I'm his first passenger of the day. He explains that Havana has been deserted because all flights from Mexico were cancelled for a week due to the swine flu. He divulges that the combination of the economic downturn and the swine flu has crippled Cubans who earn their living from tourism. 


\section{Day 3}

I spend the day walking around Centro Habana and Habana Vieja, searching for La Cartelera, the monthly newspaper that lists the theatrical events taking place in the city. (I have never known exactly where to pick up a copy, they have been given to me by caring friends and neighbors given them by their friends; in Cuba, one's network is essential!) Even the Teatro Nacional does not have one. I search two theatres, El Sótano and la Sala Adolfo Llauradó, for posters advertising their productions. At both theatres I find information about dates and times, but no descriptions of the shows. Are they Cuban plays? Adaptations? Foreign?

\section{Day 4}

I attend the Compañia Teatral Rita Montaner's production of Voy por cigarros. Written and directed by Gerardo Fulleda León, this new play takes place backstage at a cabaret, where the relationship of a married couple unravels. Despite strong acting, the play and its depressing monologue format (only the husband speaks) do not move me. It seems no more than an insular, ironic exercise in romantic memory and nuptial dysfunction. I struggle to understand why the company chose this material, why now, and why here. The piece isn't at all theatrical, has few design elements, and the actors are talking rather than doing. The audience is quieter and more passive than any I've encountered on the island. I mourn innovation because the last Montaner production I saw, in 2005, was Tony Díaz's highly imaginative version of Brene's Escandalo en la trapa, complete with detailed period costumes made of cardboard! I still buy the published text in the lobby, note the youthful audiences' lack of enthusiasm about the show, and then walk home during a blackout.

\section{Day 5}

Two Cuban friends join me for Reinaldo Montero's Fausto, produced by Teatro D'Dos at the Sala Adolfo Llauradó. I am curious why the company has chosen to restage this piece, which they mounted in 1999, rather than producing a new work. It is soon clear that Montero's modern retelling of myth, blasphemy and the quest for happiness resonates for contemporary Cubans. Stellar acting and simple but highly theatrical choices (like characters morphing into dogs, flying suitcases, and an unfinished wood frame for a house) produce an expressionistic reality. Mefistófeles' relentless pursuit 
and the conflicting desires in the play feel urgent, recognizable and timely. As Omar Valiño remarks in the program, the play revisits a crucial theme of revolutionary Cuba in recent years: "the schism between wish and process, between looking for and being, between utopia and reality." My friends, unfamiliar with Marlowe's Faust, find the commentary about souls unusual but are moved by the play's uncompromising search for happiness. They tell me that their generation, in their mid-twenties, feels this desire acutely but has few avenues in Cuba through which to pursue security and contentment.

\section{Day 6}

I go the Centro Cultural Bertolt Brecht to see Edgar Estaco's play Makarov, which was highly recommended. It is presented by Teatro del Círculo and directed by Pedro Ángel Vera, neither of whose work I am familiar with. Makarov presents marginalized members of Cuban society - whores, tramps, gays, and an idealistic student - in the thick of a fight: for their lives, for justice, for a place to call their own. An ongoing war in the city (government vs. citizens) renders all but the present moment irrelevant. The play opens with Alberto, a corrupt official, interrogating provocatively dressed women and men who sit in a cage-like cell. He is searching for his Makarov, a Soviet-era pistol. The visual representation immediately turns these attractive bodies into animals that endanger society, yet Alberto's continual violence toward them remains a gross abuse of power. There is also an elegant Don Quixote subplot that layers the meaning of the text, blurs fantasy and reality, and allows space for huge dreams. The design extends the play's meaning, as large, web-like spheres fly in from above and are rolled around by the actors in the scenes - they are expressive reminders of the entanglements we are witnessing. A love story and the power of friendship are incorporated into this disturbing portrait of violence, corruption, and hopeless repetition. I leave the theater depressed about the incessant nature of corruption, but encouraged about the state of theatre in Havana.

\section{Days $7 \& 8$}

Because new publications are scarce when they exist, I rely on the used plays, essays and posters I have always found in the Plaza de Armas. I get there and the vendors are selling everything but books. I visit UNEAC (National Union of Writers and Artists) and Casa de las Americas searching for La Cartelera, published plays, magazines, and other materials. Casa de las 
Americas has an utterly random collection of editions of Tablas and Conjunto for sale, although they aren't organized in any way. The power goes out while I am sifting through them.

\section{Day 9}

I return to the Sala Adolfo Llauradó to see $F y C h$, a play based on the Senal Paz story "El lobo, el bosque y el hombre nuevo." As I wait for a ticket, I realize that title refers directly to Tomás Gutíerrez Alea's international hit film Fresa y Chocolate. I am excited to experience $F y C h$, by inventive director Tony Díaz, hopeful that this adaptation will incorporate spectacle into the dialectic Paz created. The audience, mostly comprised of gay male couples, seems especially eager and vivacious. But because of the heat and a power failure that makes the performance begin nearly 20 minutes late, the energy dissipates considerably. David, a young and committed member of the Communist party, and Diego, an older, well-educated gay man, are played by talented actors. But, as in Voy por cigarros, they use the stage to discuss ideas, not embody them. The text flattens their complicated relationship through the use of asides and monologues which interrupt the pace and emotionality of their interaction. The characters float in unspecified space, removed from the city's social structures and economic realities. The show is the first Cuban performance I've seen that does not get a standing ovation. I leave disappointed, along with a passive audience.

\section{Day 11}

I see a poster of La Cartelera in the window of the Cine Riviera! I feverishly write down the productions listed there.

\section{Day 12}

I walk to the Sala Llauradó to see a play called Todo los hombres son iguales, but there is no performance that evening. I return to the Cine Riviera to check La Cartelera. The show is actually listed for this evening (probably a misprint) and it's now too late to see anything else. La Cartelera lists dozens more dance and musical performances than theatrical ones. I begin to suspect this is another way of catering to foreign tourists, many of whom don't speak Spanish and come to the island to see Cuban musicians and dancers. 


\section{Day 14}

Though Teatro Guiñol is known for its puppetry for children, a friend finds out that they are producing something unique for an adult audience. We walk to the Edificio Focsa to see En la calle, Nelson Dorr's "version and adaptation" of Federico Fellini's film "La Strada". The play is about the inherently theatrical world of street performers - freaks, clowns, musicians, and magicians - and requires only simple scenic, prop and costume elements. Unfamiliar with Fellini's film, I am intrigued by the virtuosic performances and horrific violence/abuse on stage before me. The play incorporates two saltimbanquis, meticulously choreographed gymnast/contortionists who act as a chorus, situating and commenting on the action. Soon we meet Zampanó (Miguel Fonseca) a macho strong man who bullies Gesolmina, a freak show performer played by dwarf actress Betty Candas, into going on the road with him. Zampanó physically, sexually and psychologically abuses the tiny, heartbreaking Gesolmina. Their evolving relationship creates a poignant tension throughout the piece. Hope comes in the form of El Loco, a musician/angel (Ernesto Lugones), who comforts Gesolmina until he is murdered by Zampanó. The saltimbanquis' exhibitions of physical dexterity in the transitions are consistent with the world onstage and provide artful reprieves from Gesolmina's painful story. The length, vigor and volume of the standing ovation for Candas moves me to tears.

\section{Day 16}

I meet with an actress friend and we discuss the many artists we know who have left Cuba in the last several years, as well as what's on stage at the moment and that no one can afford the risk of producing new material. Projects aren't being funded or have lost funding, and directors are discouraged. She shows me photos from a film she has just completed that she hopes will be screened in Miami. This sparks a conversation about the number of Cuban stage actors who are working in television and film because the pay is better and the exposure could lead to careers in other Latin American countries or the U.S. Another actress we visit laments the fact that she hasn't worked in months but is optimistic that she might have a small part in an upcoming project for Cuban television.

\section{Day 17}

I meet with Flora Lauten, co-founder and artistic director of Teatro Buendia, who agrees that there is little offered in Havana at the moment but 
anticipates a groundswell for the festival in the fall. We discuss Buendia's current project, their adaptation of Dürrenmatt's The Visit (La visita de la dama vieja), a production that she hopes will go to Chicago for the Goodman's International Festival of Latino Theatre in July 2010. The narrative of the play is about a wealthy woman who returns to her hometown and offers money to save it from ruin if the townspeople will enact justice for her. Flora explains that Buendia's cast will be much smaller than the original, and that the production will concentrate on the profound, multifaceted love story between the protagonists. She adds that Raquel Carrió, the company's dramaturg/playwright, is incorporating famous Cuban boleros into their piece to do just that. These recognizable songs will overtly tie the play to Cuba's past, while its message will still reflect the present. When I ask Flora if the company creates work for Cubans or for audiences worldwide, she insists that Cubans are part of the world, that Buendia grounds its work in identifiably Cuban contexts because their concerns, struggles and experiences resonate for many populations. Especially in this moment of economic turmoil, I can't help but agree with her.

\section{Day 18}

I am compelled to see La muerte de una viajante, Arthur Miller's Death of a Salesman, at the Teatro Hubert de Blanck. It is listed in La Cartelera for tonight, yet when I arrive at the theatre, a poster says the production opens the following week - after I've left Cuba. While walking home, I notice the performance at Teatro América that night has been cancelled because of a blackout.

\section{Postscript - There}

I think Cuban theatre is in crisis. I saw no productions by its latest generation of playwrights, only adaptations and reinventions. Actors, directors and designers were working in film and television to earn a living. Two young playwrights and four visual artists whom I know personally have left Cuba in the past three years alone. Most of the theatre I saw was uncharacteristically unimaginative, derivative even when successful, and lackluster. Design elements were limited. Most audiences, although youthful, seemed complacent and unimpressed. Not a single show I saw was sold out. I expected fewer performances than at the time of the festival, but I did not expect so much apathy about them. My Cuban friends seemed weary of the street (who could blame them - we stood in line for an hour one day to buy cucumbers) and 
content to watch telenovelas at home. A combination of uninspired productions, a lack of new/original material, concerns over swine flu and economic hardships fueled their indifference. I hope this was an anomaly, that maybe pre-preparations for the international festival in October caused the drought I experienced. History would indicate a theatrical recovery is in their future. Like many Cubans, I choose to remain optimistic.

\section{Postscript - Here}

With the Obama administration's restoration of the rights of CubanAmericans to visit the island at least once every year, there is new hope. When I return to Miami to work on the Cuban and Latino Theatre Archive, I am introduced to theatre director Alberto Sarraín. Sarraín has a company, Grupo Cultural La Má Teodora, primarily comprised of Cubans living in the U.S. and Latin America. He tells me about the production he is working on, of a play called Chamaco, written in 2005 and produced to great acclaim in Havana. Written by young Cuban playwright Abel González Melo, it will be performed in Spanish and open in late September. I am genuinely heartened by this news, that noteworthy Cuban work travels, and that new work from Cuba is being seen and heard on the island and beyond its borders.

This trip and research were funded by generous support from the Institute for Scholarship in the Liberal Arts, and the department of Film, Television, and Theatre at the University of Notre Dame.

\section{University of Notre Dame}


